\title{
STUDIES ON COPPER METABOLISM. VII. BLOOD COPPER IN PREGNANCY AND VARIOUS PATHOLOGIC STATES ${ }^{1}$
}

\author{
By M. E. LAHEY,² C. J. GUBLER, G. E. CARTWRIGHT, AND M. M. WINTROBE \\ (From the Departments of Medicine and Pediatrics, University of Utah College of Medicine, \\ Salt Lake City, Utah)
}

(Submitted for publication September 30, 1952; accepted December 31, 1952)

In the preceding paper (1) values for the copper content of whole blood, plasma and red blood cells (RBC) in the normal human subject, as determined by a new method recently devised in this laboratory (2), were recorded. The copper content of the blood in healthy individuals has been found to be remarkably constant. In various clinical conditions, on the other hand, fluctuations in whole blood and plasma copper occur. Conflicting reports make it impossible to state what part of the changes observed in disease are attributable to alterations in the content of copper in the red cells themselves.

The purpose of this report is to present data on whole blood, plasma and, particularly, RBC copper during pregnancy and in patients with various diseases.

\section{REVIEW OF LITERATURE}

In 1928, Krebs (3) discovered that serum copper is increased in pregnancy as well as in acute and chronic infectious diseases. These observations have since been confirmed by many investigators (4-19). Hypercupremia has also been observed in leukemia $(5,7,9,16)$, Hodgkin's disease $(16)$, aplastic anemia $(5,16)$, iron deficiency anemia $(5,9,16,20)$, pernicious anemia $(5,7$, $9,16)$, sickle cell anemia (9), thalassemia (16), polycythemia vera (9), purpura (9), Banti's syndrome $(9,16)$, hepatolenticular degeneration $(21)$ and various other types of liver disease $(5,7,16)$, Addison's disease $(7,22)$, diabetes $(7)$, the "collagen diseases" $(5,9,16)$, carcinoma of various types $(5,7,9)$, hyperthyroidism $(5,7,23)$, allergic reactions $(5)$, malaria $(5,9)$, arsenic poisoning $(5,9)$, schizophrenia and in various disorders of the central nervous system $(5,9)$.

1 This investigation was supported by a research grant (RG 25 [C6]) from the National Institutes of Health, Public Health Service.

2 National Research Council Fellow in the Medical Sciences, 1949-1951.
According to all $(5,8,13,14)$ but one $(12)$ investigator, the serum copper increases in early pregnancy and continues to rise to reach levels at full term approximately twice those found in non-pregnant subjects. Normal values reappear during the first two months post-partum $(4,13)$. The serum copper level in pre-eclampsia shows a small but significant increase over the usual elevation observed in pregnancy, but there seems to be no correlation between the severity of toxemia and the height of the serum copper level (13).

The increase in plasma copper that occurs in most acute and chronic infections begins soon after the onset of the infection and returns to normal during convalescence (16). In this respect, its behavior is like that of the so-called acute phase reactants and of the erythrocyte sedimentation rate (24). The relationship between the hypercupremia and alterations in the serum proteins will be discussed in a subsequent paper in this series (25). Whether any change occurs in the copper content of the red blood cells along with the increased plasma copper in infection is unsettled. Heilmeyer observed a reduction in $\mathrm{RBC}$ copper and postulated that there is a shift from erythrocytes to plasma (5). Still other work indicates that RBC copper remains constant in spite of considerable fluctuation in serum copper (26). It is worth emphasizing that these divergent claims have all been made on the basis of calculated values for $\mathrm{RBC}$ copper, the inaccuracies of which have been stressed $(2,26)$.

In addition to the association of hypercupremia with pathologic conditions accompanied by an increase in body temperature and in sedimentation rate, it has been stated that the plasma copper content is dependent on the functional state of the thyroid gland. Hypercupremia, which usually decreased with successful treatment, has been observed in thyrotoxicosis $(5,7)$. In hypothyroidism $(5,7,12,23)$ low normal values for plasma 
copper have been reported. However, no clear correlation between the serum copper level and the basal metabolic rate has been demonstrated (23).

In patients with carcinoma of various types, Heilmeyer showed that the RBC copper is often decreased, with the result that the distribution of copper in the cells and serum is similar to that noted by him in infections (5). Patients with hepatic neoplasms have been found to have less copper in the liver than is normal and experimental evidence has been recorded that the presence of neoplasms in rats is associated with a significant decrease in the copper concentration in the liver $(27,28)$.

Hypocupremia has been noted only in hepatolenticular degeneration (29) and in one patient with severe nephritis and hypoalbuminemia. The copper content of cord blood when compared with that of maternal blood is distinctly low $(4,6,8,9)$. In hemochromatosis (30), normal values have been reported.

\section{MATERIALS AND METHODS}

The hematologic methods used in this study have been described elsewhere (31). Other methods used for the various determinations were as follows: that of Gubler, Lahey, Ashenbrucker, Cartwright and Wintrobe for whole blood, plasma and RBC copper (2); a modification of Barkan and Walker's method for plasma iron (32); and that of Cartwright and Wintrobe for the plasma ironbinding capacity (33).

Blood samples were obtained from the pregnant women in the early afternoon, while all others were obtained in the morning.

In studying the utilization of copper administered intravenously in two patients with chronic infections, " $\mathrm{Cu}$ pralene" (Specia, Paris, France) was used. This is allylcuprothiocarbamide and contains 19.93 per cent copper. One hundred milligrams, diluted in $15 \mathrm{ml}$. sterile physiological saline, was administered rapidly into a vein of one extremity and subsequent samples of blood were taken from another site.

\section{RESULTS}

1. Normal values. The values for whole blood, plasma and RBC copper listed in Tables I and IV are those previously reported from this laboratory

TABLE I

Values for blood copper and iron in various clinical conditions compared with the normal

\begin{tabular}{|c|c|c|c|c|c|c|c|c|c|}
\hline \multirow[b]{2}{*}{ Condition } & \multirow{2}{*}{ 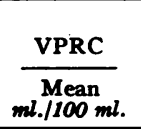 } & \multicolumn{2}{|c|}{$\begin{array}{l}\text { Whole blood copper } \\
\mu \mathrm{g} . / 100 \mathrm{ml} \text {. }\end{array}$} & \multicolumn{2}{|c|}{$\begin{array}{c}\begin{array}{c}\text { Plasma copper } \\
\mu \mathrm{g} .1100 \mathrm{ml} .\end{array} \\
\end{array}$} & \multicolumn{2}{|c|}{$\begin{array}{c}\mathrm{RBC} \text { copper } \\
\mu \mathrm{g} . / 100 \mathrm{ml} .\end{array}$} & \multicolumn{2}{|c|}{$\begin{array}{c}\text { Plasma iron } \\
\mu \mathrm{g} . / 100 \mathrm{ml} .\end{array}$} \\
\hline & & $\begin{array}{c}\text { No. } \\
\text { subjects }\end{array}$ & $\begin{array}{l}\text { Mean } \\
\pm \text { S.D. }\end{array}$ & $\begin{array}{c}\text { No. } \\
\text { subjects }\end{array}$ & $\begin{array}{l}\text { Mean } \\
\pm \text { S.D. }\end{array}$ & $\begin{array}{c}\text { No. } \\
\text { subjects }\end{array}$ & $\begin{array}{l}\text { Mean } \\
\pm \text { S.D. }\end{array}$ & $\begin{array}{c}\text { No. } \\
\text { subjects }\end{array}$ & $\begin{array}{l}\text { Mean } \\
\pm \text { S.D. }\end{array}$ \\
\hline Normal & 48 & 63 & $\begin{array}{r}98 \\
\pm 13\end{array}$ & 63 & $\begin{array}{r}109 \\
\pm 17\end{array}$ & 31 & $\begin{array}{r}115 \\
\pm 22\end{array}$ & 27 & $\begin{array}{r}115 \\
\pm 42\end{array}$ \\
\hline Pregnancy. & 37 & 30 & $\begin{array}{r}169 \\
\pm 26\end{array}$ & 30 & $\begin{array}{r}222 \\
\pm 38\end{array}$ & 11 & $\begin{array}{r}130 \\
\pm 30\end{array}$ & 30 & $\begin{array}{r}91 \\
\pm 38\end{array}$ \\
\hline Infection & 41 & 37 & $\begin{array}{r}141 \\
\pm 30\end{array}$ & 38 & $\begin{array}{r}167 \\
\pm 35\end{array}$ & 18 & $\begin{array}{r}116 \\
\pm 34\end{array}$ & 37 & $\begin{array}{r}57 \\
\pm 28\end{array}$ \\
\hline Acute leukemia & 27 & 19 & $\begin{array}{r}195 \\
\pm 83\end{array}$ & 21 & $\begin{array}{r}236 \\
\pm 79\end{array}$ & 5 & 98 & 17 & $\begin{array}{r}171 \\
\pm 70\end{array}$ \\
\hline Chronic leukemia & 39 & 21 & $\begin{array}{r}119 \\
\pm 24\end{array}$ & 22 & $\begin{array}{r}148 \\
\pm 31\end{array}$ & 12 & $\begin{array}{r}101 \\
\pm 39\end{array}$ & 21 & $\begin{array}{r}113 \\
\pm 54\end{array}$ \\
\hline Hodgkin's disease & 40 & 14 & $\begin{array}{r}142 \\
\pm 50\end{array}$ & 14 & $\begin{array}{r}171 \\
\pm 58\end{array}$ & 8 & 109 & 13 & $\begin{array}{r}78 \\
\pm 24\end{array}$ \\
\hline Hemochromatosis & - & 3 & 103 & 14 & $\begin{array}{r}134 \\
\pm 24\end{array}$ & - & 一 & 14 & $\begin{array}{r}234 \\
\pm 62\end{array}$ \\
\hline Pernicious anemia & 27 & 10 & $\begin{array}{r}111 \\
\pm 29\end{array}$ & 11 & $\begin{array}{r}121 \\
\pm 36\end{array}$ & 2 & 98 & 9 & $\begin{array}{r}173 \\
\pm 55\end{array}$ \\
\hline $\begin{array}{l}\text { Iron deficiency anemi } \\
\text { adults }\end{array}$ & mia 30 & 9 & $\begin{array}{r}114 \\
\pm 16\end{array}$ & 9 & $\begin{array}{r}132 \\
\pm 21\end{array}$ & 3 & 109 & 9 & $\begin{array}{r}26 \\
\pm 7\end{array}$ \\
\hline infants & 28 & 24 & $\begin{array}{r}155 \\
\pm 30\end{array}$ & 26 & $\begin{array}{r}168 \\
\pm 37\end{array}$ & 14 & $\begin{array}{r}152 \\
\pm 33\end{array}$ & 25 & $\begin{array}{r}31 \\
\pm 7\end{array}$ \\
\hline
\end{tabular}


TABLE II

The effect of corticotrophin (ACTH) therapy on the plasma copper and the clinical condition of four patients with acute leukemia

\begin{tabular}{|c|c|c|c|c|c|}
\hline \multirow[b]{2}{*}{ Patient } & \multicolumn{2}{|c|}{ ACTH } & \multicolumn{2}{|c|}{$\begin{array}{l}\text { Plasma copper } \\
\text { нg./100 ml. }\end{array}$} & \multirow[b]{2}{*}{$\begin{array}{c}\text { Clinical } \\
\text { improvement }\end{array}$} \\
\hline & $\begin{array}{l}\text { Total } \\
\text { dose } \\
g m .\end{array}$ & $\begin{array}{l}\text { Duration } \\
\text { of therapy } \\
\text { days }\end{array}$ & $\begin{array}{c}\text { Before } \\
\text { therapy }\end{array}$ & $\begin{array}{c}\text { After } \\
\text { therapy }\end{array}$ & \\
\hline $\begin{array}{l}\text { P. L. } \\
\text { G. C. } \\
\text { H. McE. } \\
\text { J. W. }\end{array}$ & $\begin{array}{l}2.08 \\
1.77 \\
2.83 \\
0.69\end{array}$ & $\begin{array}{l}35 \\
40 \\
33 \\
12\end{array}$ & $\begin{array}{l}330 \\
206 \\
252 \\
291\end{array}$ & $\begin{array}{r}120 \\
75 \\
170 \\
168\end{array}$ & $\begin{array}{l}\text { Yes } \\
\text { Yes } \\
\text { No } \\
\text { No }\end{array}$ \\
\hline
\end{tabular}

TABLE III

Determinations made on 12 infants with anemia due to iron deficiency before and after therapy *

\begin{tabular}{|c|c|c|c|c|c|}
\hline \multirow[b]{2}{*}{$\begin{array}{l}\text { Iron deficiency } \\
\text { anemia }\end{array}$} & \multirow[b]{2}{*}{$\begin{array}{c}\text { Plasma } \\
\text { copper } \\
\mu \mathrm{g} / 100 \mathrm{ml} .\end{array}$} & \multirow[b]{2}{*}{$\begin{array}{c}\text { RBC } \\
\text { copper } \\
\mu g . / 100 \mathrm{ml} .\end{array}$} & \multirow[b]{2}{*}{$\begin{array}{c}\text { Plasma } \\
\text { iron } \\
\mu \mathrm{g} . / 100 \mathrm{ml} .\end{array}$} & \multicolumn{2}{|c|}{ Iron-binding capacity } \\
\hline & & & & $\begin{array}{c}\text { Total } \\
\text { Mg./100 ml. } \\
\text { plasma }\end{array}$ & $\begin{array}{c}\text { Saturation } \\
\text { per } \\
\text { cent }\end{array}$ \\
\hline $\begin{array}{l}\text { Before therapy } \\
\text { After therapy }\end{array}$ & $\begin{array}{l}170 \\
154\end{array}$ & $\begin{array}{l}149 \\
133\end{array}$ & $\begin{array}{l}31 \\
78\end{array}$ & $\begin{array}{l}404 \\
352\end{array}$ & $\begin{array}{r}8 \\
22\end{array}$ \\
\hline
\end{tabular}

* Figures refer to the mean.

(1). The value for plasma iron was derived from determinations on 27 of the 63 normal subjects; 17 were male and 10 were female. A significantly lower value was found in females (106 $\mu \mathrm{g}$. per 100 ml.) as compared with males (121 $\mu \mathrm{g}$. per $100 \mathrm{ml}$.) but, because all of the groups of clinical conditions except pregnancy include patients of both sexes, the mean value of $115 \mu \mathrm{g}$. per $100 \mathrm{ml}$. is given in the tables.

The normal average value for plasma copper is significantly higher in females ( 116 vs. $105 \mu \mathrm{g}$. per $100 \mathrm{ml}$.) but for a similar reason, the mean value of $109 \mu \mathrm{g}$. per $100 \mathrm{ml}$. is listed in the tables.

From the comprehensive study of Axtrup (34) and from the few determinations made in this laboratory on normal children, it seems that blood copper values are the same in normal children and adults. However, we have observed rather striking differences in the values in certain pathological conditions in children as compared with adults. They will, therefore, be considered separately.

2. Pregnancy. The results of copper and iron determinations during the last trimester of pregnancy are presented in Table $I$. In none of the patients was toxemia a complicating factor.

Whole blood and plasma copper determinations in the 30 pregnant subjects ranged from 130 to 277 $\mu \mathrm{g}$. per $100 \mathrm{ml}$. blood and from 150 to $285 \mu \mathrm{g}$. per $100 \mathrm{ml}$. plasma, and were uniformly greater than three standard deviations from the mean for normal, non-pregnant women (whole blood copper, $100 \pm 11 \mu \mathrm{g}$. per $100 \mathrm{ml}$.; plasma copper $116 \pm$ $16 \mu \mathrm{g}$. per $100 \mathrm{ml}$.).

RBC copper determinations were made in 11 of the 30 subjects. The mean for the group was $130 \mu \mathrm{g}$. per $100 \mathrm{ml}$. RBC and was not significantly different from the mean of $122 \mu \mathrm{g}$. per $100 \mathrm{ml}$. determined in 12 normal, non-pregnant women. Ten of the 11 determinations were within the normal range. The single abnormal value of $190 \mu \mathrm{g}$. per $100 \mathrm{ml}$. was found in a woman whose plasma iron and complete blood count were within normal limits.

The ratio of $\mathrm{RBC}$ copper to plasma copper for the group as a whole was 0.58 or approximately one-half that in non-pregnant women (1.05). The data indicate that the increase in whole blood copper in pregnancy is due entirely to an increase in plasma copper. The copper content of the average corpuscle was essentially the same as in the normal (100 $\mu \mu \mu \mathrm{g}$.).

Plasma iron determinations were made in 30 subjects and did not differ significantly from those in the normal, non-pregnant female (106 $\mu \mathrm{g}$. per $100 \mathrm{ml}$. plasma).

3. Infections. The results in patients with various infections are presented in Table I. The illnesses were subacute or chronic: 12 subjects had 
TABLE IV

Results of determinations in miscellarreous clinical conditions

\begin{tabular}{|c|c|c|c|c|c|c|c|c|c|}
\hline \multirow[b]{2}{*}{ Condition } & \multirow{2}{*}{$\frac{\text { VPRC }}{\substack{\text { Mean } \\
\text { ml./100 ml. }}}$} & \multicolumn{2}{|c|}{ Whole blood copper } & \multicolumn{2}{|c|}{ Plasma copper } & \multicolumn{2}{|c|}{ RBC copper } & \multicolumn{2}{|c|}{ Plasma iron } \\
\hline & & $\begin{array}{l}\text { No. } \\
\text { subjects }\end{array}$ & $\begin{array}{c}\text { Mean } \\
\text { (range) } \\
\mu_{8} .1100 \mathrm{ml} .\end{array}$ & $\begin{array}{l}\text { No. } \\
\text { subjects }\end{array}$ & $\begin{array}{c}\text { Mean } \\
\text { (range) } \\
\text { m8.1100 ml. }\end{array}$ & $\begin{array}{l}\text { No. } \\
\text { subjects }\end{array}$ & $\begin{array}{c}\text { Mean } \\
(\text { range }) \\
\mu g . / 100 \\
m l .\end{array}$ & $\begin{array}{l}\text { No. } \\
\text { subjects }\end{array}$ & $\begin{array}{c}\begin{array}{c}\text { Mean } \\
(\text { range }) \\
\text { H. } / 1100 \mathrm{ml} .\end{array} \\
\end{array}$ \\
\hline Normal & 48 & 63 & $\begin{array}{c}98 \\
(69-117)\end{array}$ & 63 & $\begin{array}{c}109 \\
(68-143)\end{array}$ & 31 & $\begin{array}{c}115 \\
(84-159)\end{array}$ & 27 & $\begin{array}{c}115 \\
(56-242)\end{array}$ \\
\hline Aplastic anemia & 28 & 8 & $\begin{array}{c}130 \\
(97-160)\end{array}$ & 8 & $\begin{array}{c}152 \\
(119-180)\end{array}$ & 3 & $\begin{array}{c}86 \\
(69-111)\end{array}$ & 8 & $\begin{array}{c}203 \\
(103-272)\end{array}$ \\
\hline Hyperthyroidism & 46 & 6 & $\begin{array}{c}108 \\
(93-130)\end{array}$ & 7 & $\begin{array}{c}140 \\
(108-160)\end{array}$ & 5 & $\begin{array}{c}70 \\
(51-92)\end{array}$ & 7 & $\begin{array}{c}124 \\
(62-208)\end{array}$ \\
\hline Hypothyroidism & 37 & 5 & $\begin{array}{c}105 \\
(90-117)\end{array}$ & 7 & $\begin{array}{c}126 \\
(108-149)\end{array}$ & 6 & $\begin{array}{c}103 \\
(81-134)\end{array}$ & 5 & $\begin{array}{c}83 \\
(58-113)\end{array}$ \\
\hline Collagen disease & 31 & 6 & $\begin{array}{c}107 \\
(70-130)\end{array}$ & 6 & $\begin{array}{c}123 \\
(78-141)\end{array}$ & - & - & 6 & $\begin{array}{c}72 \\
(40-96)\end{array}$ \\
\hline $\begin{array}{l}\text { Polycythemia } \\
\text { vera }\end{array}$ & 60 & 3 & $\begin{array}{c}100 \\
(93-107)\end{array}$ & 5 & $\begin{array}{l}119 \\
(96-154)\end{array}$ & 3 & $\begin{array}{c}84 \\
(47-146)\end{array}$ & 3 & $\begin{array}{c}141 \\
(44-202)\end{array}$ \\
\hline Nephrosis & 44 & 3 & $\begin{array}{c}70 \\
(53-80)\end{array}$ & 3 & $\begin{array}{c}80 \\
(60-96)\end{array}$ & 1 & 119 & 3 & $\begin{array}{c}62 \\
(30-97)\end{array}$ \\
\hline $\begin{array}{l}\text { Hepatolenticular } \\
\text { degeneration }\end{array}$ & 42 & 2 & $\begin{array}{c}79 \\
(78-80)\end{array}$ & 3 & $\begin{array}{c}55 \\
(40-68)\end{array}$ & 2 & $\begin{array}{c}110 \\
(91-130)\end{array}$ & 3 & $\begin{array}{c}64 \\
(56-75)\end{array}$ \\
\hline
\end{tabular}

VPRC signifies volume of packed red cells.

tuberculosis in its various clinical forms, nine had rheumatic fever or rheumatoid arthritis, five had empyema, and the remainder had bacterial endocarditis, pneumonia, bronchiectasis, typhoid fever or pyogenic skin abscesses. The children in this series, nine girls and five boys, ranged from 2 to 15 years of age, and the adults, six women and 18 men, were 15 to 74 years of age.

Whole blood copper determinations were made on 14 children and 23 adults. The mean for the former $(160 \mu \mathrm{g}$. per $100 \mathrm{ml}$. blood) was significantly higher than that for the latter $(130 \mu \mathrm{g}$. per $100 \mathrm{ml}$.). The mean for the entire group was 141 $\mu \mathrm{g}$. per $100 \mathrm{ml}$. Only in 22 per cent of the cases (seven adults and one child) was there no significant hypercupremia. All seven adults had chronic pulmonary disease, four with empyema. The child was convalescing from acute rheumatic fever.

Plasma copper determinations were made on 14 children and 24 adults. Again the mean for the former (183 $\mu \mathrm{g}$. per $100 \mathrm{ml}$. plasma) was significantly higher than that for the latter (157 $\mu$ g. per $100 \mathrm{ml}$.). The mean for the group was $167 \mu \mathrm{g}$. per $100 \mathrm{ml}$. Twenty-seven of the 38 patients, or 71 per cent, exhibited hypercupremia. In 10 the values were within the normal range, while in one adult the low value of $74 \mu \mathrm{g}$. per $100 \mathrm{ml}$. was observed. The ten with normal values included two children convalescing from rheumatic fever and eight adults with chronic pulmonary disease, four of whom had empyema.

RBC copper determinations were made on six children and 12 adults. The mean for the group $(116 \mu \mathrm{g}$. per $100 \mathrm{ml}$. RBC) was essentially the same as for the normal. The individual values were within the normal range in all of the children and in eight of the adults ( 78 per cent of the whole group). In two adults low and in two high values for $R B C$ copper were found.

In general, then, infections tended to produce an elevation in whole blood and plasma copper, while the RBC copper content remained unchanged. In certain patients, however, significant deviations from the usual reaction were observed. Thus, in four adults with empyema, normal whole blood and plasma copper values were observed. In one of these the RBC copper was low. No correlation was apparent between the $\mathrm{RBC}$ or plasma copper values and the age of the patient, the duration of the illness, or the presence or absence of anemia.

The ratio of RBC copper to plasma copper for 
the entire group was markedly reduced (0.69). The mean corpuscular copper was the same as for the normal (100 $\mu \mu \mu \mathrm{g}$.). Thus the increase in whole blood copper in infection is due entirely to an increase in plasma copper.

Plasma iron determinations were carried out in 14 children and 23 adults. While in three children and one adult the values ranged from 92 to $172 \mu \mathrm{g}$. per $100 \mathrm{ml}$. plasma and were thus within normal limits, the mean value for the entire group was low ( $57 \mu \mathrm{g}$. per $100 \mathrm{ml}$.), thus confirming previous reports from this laboratory (15).

In order to determine whether patients with chronic infections and hypercupremia are capable of removing copper from the plasma at the normal rate, a patient with chronic tuberculosis was given $100 \mathrm{mg}$. of "Cupralene" (19.93 mg. of copper) intravenously and the subsequent changes in the plasma and red cell copper level were measured. The results are presented in Figure 1 and are compared with the mean values in four normal human subjects given the same amount of organic copper compound.

In the normal individuals the plasma copper level increased within 10 minutes to between 545 and $740 \mu \mathrm{g}$. per $100 \mathrm{ml}$. plasma, thereafter declining rapidly to reach approximately the initial values in four hours. A similar disappearance rate was observed in the patient with chronic pulmonary tuberculosis.

4. Acute leukemia. Whole blood copper determinations were carried out in 12 children and in seven adults and were above the limits established for the normal in 16 (84 per cent). Similarly, plasma copper values were elevated in 19 (90 per cent) of the 14 children and seven adults studied. In fact, the only normal values (one child with normal whole blood copper and two adults with normal whole blood and plasma copper) were observed in patients who had received blood transfusions a few days before the determinations were made. Extreme hypercupremia, e.g., values above $300 \mu \mathrm{g}$. per $100 \mathrm{ml}$., were observed in five patients (24 per cent).

Determinations on both adults and children with acute leukemia in relapse are included in the mean values in Table $I$. In the children the values for whole blood and plasma copper (221 and $265 \mu \mathrm{g}$. per $100 \mathrm{ml}$,, respectively) were significantly

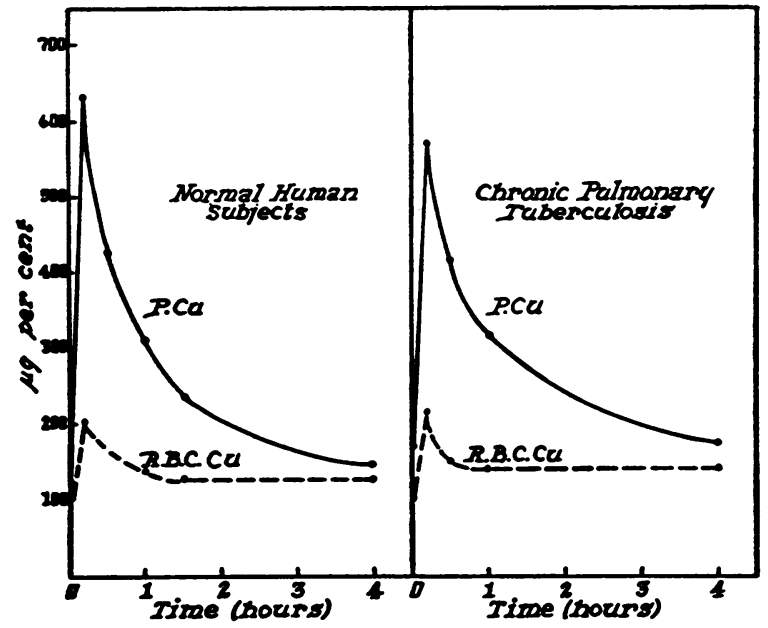

Fig. 1. Alterations in Plasma and Red Blood Celi Copper in a Patient with a Chronic Infection as Compared with Normal Human Subjects (Mean of Four Individuals) following the Intravenous ADministration of 100 Mg. of "Cupralene"

higher than in the adults (150 and $179 \mu \mathrm{g}$. per $100 \mathrm{ml}$., respectively).

$\mathrm{RBC}$ copper determinations were made in four children and one adult, all but one ( $58 \mu \mathrm{g}$. per 100 ml.) were within normal limits.

As in pregnancy and infections, the ratio of RBC copper to plasma copper in acute leukemia was markedly reduced $(0.42)$, while the amount of copper in the average red corpuscle was essentially unaltered (88 $\mu \mu \mu \mathrm{g}$.).

The mean values for plasma iron in six adults (133 $\mu \mathrm{g}$. per $100 \mathrm{ml}$.) as well as in the 11 children (192 $\mu \mathrm{g}$. per $100 \mathrm{ml}$.) were above the normal of $115 \mu \mathrm{g}$. per $100 \mathrm{ml}$. The hyperferremia was in most instances slight in degree. Only in five (29 per cent) of the 17 patients studied were the plasma iron values in excess of the normal limits.

A favorable response to the administration of corticotrophin (ACTH) in a patient with acute leukemia was accompanied by a decrease in blood copper values, as shown in Figure 2, and relapse was associated with a return to the previously high copper levels. A similar result was obtained in a second patient (Table II). In two other patients with acute leukemia a decrease in plasma copper occurred even though there was no demonstrable clinical improvement.

5. Chronic leukemia and lymphosarcoma. Ten patients with chronic myelocytic leukemia, eight 


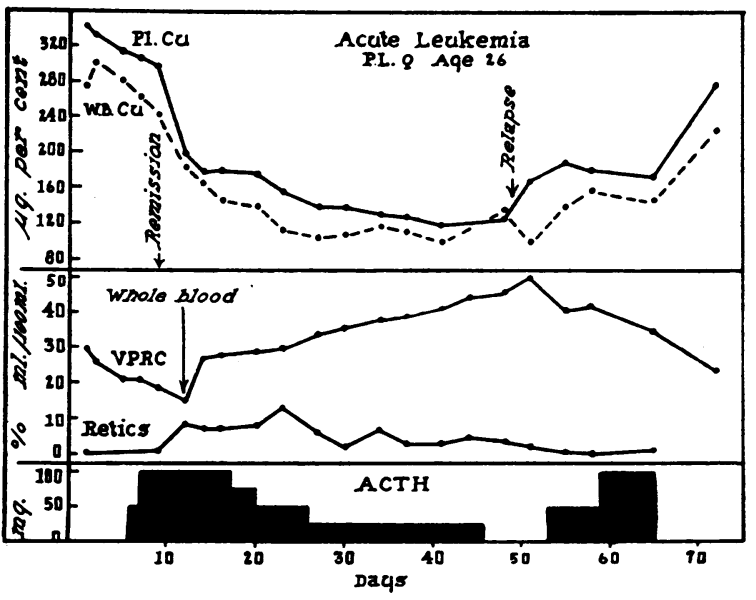

Fig. 2. Changes in Plasma and Whole Blood Copper in a Patient with Acute Leukemia

The hypercupremia was temporarily abolished in response to corticotrophin (ACTH) therapy but returned as clinical relapse occurred.

$\mathrm{Pl}$. $\mathrm{Cu}$, plasma copper; WB $\mathrm{Cu}$, whole blood copper; VPRC, volume of packed red cells; Retics, reticulocytes.

with chronic lymphocytic leukemia and four with lymphosarcoma are included under the heading of "chronic leukemia" in Table I. All determinations were made prior to treatment with $\mathrm{X}$-ray, nitrogen mustard, or urethane. While the mean values for whole blood (119 $\mu \mathrm{g}$. per $100 \mathrm{ml}$.) and plasma copper (148 $\mu \mathrm{g}$. per $100 \mathrm{ml}$.) were higher than in the normal, in 12 patients ( 57 per cent) the whole blood copper values were within the normal limits and in ten ( 45 per cent) the plasma copper levels were normal. Only in one patient, a case of chronic myelocytic leukemia, was there a slightly lowered value for whole blood copper.

$\mathrm{RBC}$ copper determinations were made in 12 patients and were found to be normal in seven, high in one and low in four. The mean value for $\mathrm{RBC}$ copper was not significantly different from the normal.

Again it may be seen that, as in the other conditions studied, the amount of copper in the average corpuscle was not significantly altered ( $88 \mu \mu \mu \mathrm{g}$.) in chronic leukemia and the hypercupremia was the result of an increase in plasma copper.

Plasma iron determinations were made in 21 patients and were within normal limits in all but one patient. The plasma iron in this patient with chronic lymphocytic leukemia was $282 \mu \mathrm{g}$. per 100 $\mathrm{ml}$.
6. Hodgkin's disease. Fourteen patients with Hodgkin's disease were studied. Whole blood and plasma copper values were significantly higher and plasma iron values were significantly lower than in the normal. Three boys, ages 11,12 , and 12 years, respectively, are included in the group.

Whole blood copper values were elevated in eight of the 14 patients, and plasma copper was elevated in nine. The highest values for whole blood ( 230 and $256 \mu \mathrm{g}$. per $100 \mathrm{ml}$.) and plasma copper (282 and $297 \mu \mathrm{g}$. per $100 \mathrm{ml}$.) were found in two of the three boys studied, in both of whom there was widespread visceral involvement.

RBC copper determinations were made on eight patients and all were within normal limits.

Plasma iron determinations were carried out on 13 patients. The mean for the group ( $78 \mu \mathrm{g}$. per $100 \mathrm{ml}$.) was significantly lower than normal.

The ratio of cell copper to plasma copper, and the mean corpuscular copper were 0.64 and 95 $\mu \mu \mu \mathrm{g}$., respectively.

7. Hemochromatosis. Blood specimens from patients with hemochromatosis were kindly furnished us by Dr. F. Gardner, Boston, and by Dr. Ian Wood, Melbourne, Australia. Eleven were sent by the latter and make up a part of the material studied by Althausen and his associates (35). From the data in Table I it may be seen that both the plasma copper and the plasma iron values were significantly above the normal. In four (29 per cent) of the 14 patients the values for plasma copper were distinctly elevated, ranging from 143 to $187 \mu \mathrm{g}$. per $100 \mathrm{ml}$., and in an additional three (21 per cent) the values were at the upper limits of normal. In 12 ( 86 per cent) of the 14 patients the plasma iron values were distinctly elevated, ranging from 202 to $318 \mu \mathrm{g}$. per $100 \mathrm{ml}$. The three whole blood copper determinations that could be done were within normal limits and were accompanied by normal values for plasma copper.

8. Pernicious anemia. In patients with pernicious anemia in relapse (Table I) a slight increase in the average whole blood and plasma copper was noted for the entire group but in 50 per cent the whole blood copper was normal and in 45 per cent the plasma copper was normal. In two patients both the whole blood and plasma copper were low. While the copper concentration of 100 $\mathrm{ml}$. of macrocytes in the two patients studied was within normal limits, the copper content of the 
average single cell was $126 \mu \mu \mu g$., that is, about 25 per cent greater than in the normal cell.

Plasma iron determinations were within normal limits in five ( 56 per cent) of the nine patients studied, and elevated in the remainder. The mean value of $173 \mu \mathrm{g}$. per $100 \mathrm{ml}$. was significantly higher than normal.

Blood copper and iron determinations were made on several patients during therapy. The characteristic hypoferremia which develops during the period of rapid blood regeneration in response to therapy (31) was observed, but the changes in whole blood and plasma copper were insignificant.

9. Iron deficiency anemia. The results in patients with anemia due to iron deficiency are shown in Table I and include determinations in nine adults and in 26 infants, the latter ranging in age from seven to 24 months.

Whole blood copper determinations were normal or elevated in both groups. In the majority (67 per cent) of the adults the values were within normal limits, while in the majority ( 83 per cent) of the infants, they were high. Essentially the same was true of the plasma copper determinations; that is, in 67 per cent of the adults the values were within the normal limits, while in 69 per cent of the infants the values were high. It is worth emphasizing that in no instance, either in adults or infants, was hypocupremia noted. The lowest whole blood copper in the adults was $93 \mu \mathrm{g}$. per $100 \mathrm{ml}$. and in the infants $101 \mu \mathrm{g}$. per $100 \mathrm{ml}$.; the lowest plasma copper in the adults was $102 \mu \mathrm{g}$. per $100 \mathrm{ml}$., and in the infants $117 \mu \mathrm{g}$. per $100 \mathrm{ml}$.

$\mathrm{RBC}$ copper determinations were within normal limits in all three adults and in nine ( 64 per cent) of the 14 infants so examined. In the five remaining infants ( 36 per cent) the $\mathrm{RBC}$ copper was elevated.

Thus, in adults with iron deficiency anemia, blood copper values were normal or slightly elevated and the ratio of cell copper to plasma copper was only very slightly reduced. The average copper content of the microcytes (73 $\mu \mu \mu \mathrm{g}$. per cell) was reduced in proportion to the reduction in cell size (the average mean corpuscular volume was $67 \mathrm{cu} . \mu$ ) so that the corpuscular copper concentration was normal in the microcytes. In the infants, however, the plasma and RBC copper values were usually elevated. The average copper con- tent of the microcytes (91 $\mu \mu \mu \mathrm{g}$. per cell) was not reduced, as in the adults, in proportion to the reduction in cell size (the average mean corpuscular volume was 59 cu. $\mu$ ). From these data it is evident that in the microcytes of iron deficiency anemia in infants the concentration of copper is increased.

The plasma iron determinations were characteristically quite low in all the patients studied.

The results of studies in 12 infants with iron deficiency anemia before and after therapy are shown in Table III. An average interval of 33 days, with a range of 17 to 62 days, separated the two sets of determinations. In this period of time, a slight decrease in plasma and RBC copper occurred in association with therapy and was accompanied by an increase in plasma iron, decrease in iron-binding capacity of the plasma, and consequent increase in the per cent saturation of the iron-binding protein. That restoration to normal values for plasma and $R B C$ copper would have occurred as more time elapsed and as other blood values returned to normal is suggested by data on five of the infants studied. In these five there was an average interval of 42 days between the determinations. The RBC copper decreased from 142 to $108 \mu \mathrm{g}$. per $100 \mathrm{ml}$., while the plasma copper remained slightly elevated. The volume of packed red cells increased from 27 to $40 \mathrm{ml}$. per $100 \mathrm{ml}$. in the same interval of time.

10. Observations in a variety of clinical conditions other than those already discussed are presented in Table IV. While the groups consisted of relatively small numbers of patients, certain results are worthy of comment.

The hypercupremia described in patients with aplastic or primary refrectory anemia $(5,16)$ appears to be due entirely to an increase in plasma copper since $\mathrm{RBC}$ copper was not found to be altered significantly.

The patients with hyperthyroidism had received no therapy or had been inadequately treated at the time the determinations were made. The finding of elevated plasma copper in four ( 57 per cent) of the patients confirms the observations of other investigators, and the disproportionate increase in plasma copper in comparison with whole blood copper substantiates the finding of low RBC copper (mean of $70 \mu \mathrm{g}$. per $100 \mathrm{ml}$.) in four patients. Except for the finding of elevated plasma cop- 
per levels in two patients with untreated or inadequately treated hypothyroidism, the blood copper values were normal in patients with this disease. All the plasma iron values were within the normal range but were at the lower limits of normal.

No clear correlation between plasma copper levels and the basal metabolic rate could be made out in our cases. It should be pointed out, however, that the total number of cases of hyper- and hypothyroidism studied was small.

In the series of patients representing the socalled collagen diseases, whole blood copper was high and plasma copper normal in the one patient with dermatomyositis, and the copper values were normal in the one case of periarteritis nodosa. The plasma iron values were normal to low.

In polycythemia vera, the results were within normal limits, except for an elevated plasma copper in one patient and reduced values for $R B C$ copper in two. In three children with "lipoid" nephrosis low whole blood and plasma copper values were found.

In three patients with hepatolenticular degeneration (Wilson's disease) the plasma copper level was consistently low. Red cell copper determinations were performed on two of the patients and the values were normal in both.

\section{DISCUSSION}

With few exceptions, the values for whole blood and plasma copper in pregnancy and in various pathologic conditions in this study are in agreement with those of the majority of other investigators, and consist, in brief, of normal to elevated values in these conditions. Significant hypocupremia was observed only in "lipoid" nephrosis and in hepatolenticular degeneration (Wilson's disease). This is of interest in view of the reported increase in urinary excretion of copper in patients with these two diseases $(36,37)$.

The recorded observations on blood copper in various clinical conditions indicate that $R B C$ copper remains remarkably constant, the hypercupremia being entirely the result of an increase in the copper content of the plasma. To illustrate these relationships, determinations made on 37 subjects, selected at random from the adult normal and pathologic material, have been plotted, as shown in Figure 3. While the correlation between plasma

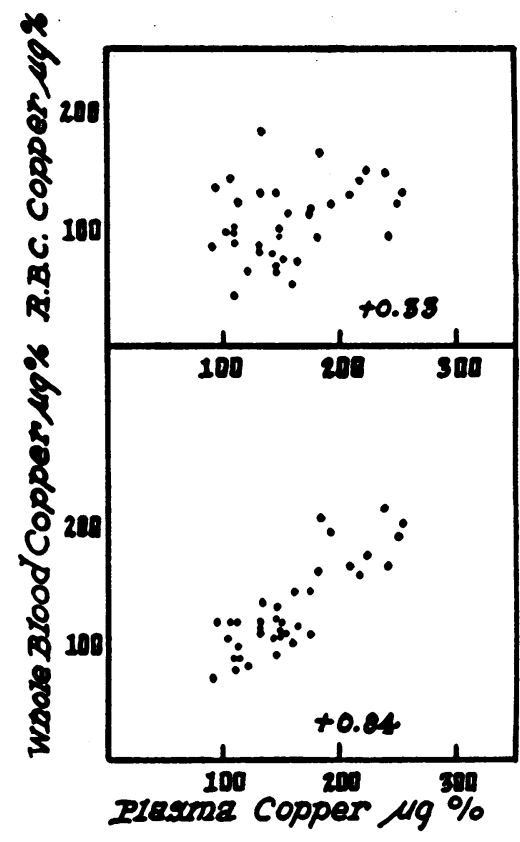

Fig. 3. Correlation of Plasma Copper with Whole Blood Copper aNd with RBC Copper

The correlation coefficients were +0.84 and +0.33 , respectively.

and $\mathrm{RBC}$ copper is poor, that between plasma and whole blood copper is very good, substantiating the observations of Munch-Petersen (26).

Significant alterations from the normal in red cell copper were consistently observed only in pernicious anemia, iron deficiency anemia in infants, and in patients with hyperthyroidism. Although the amount of copper in a hundred milliliters of packed cells obtained from patients with pernicious anemia was not altered from the normal, the amount of copper per cell was increased since fewer red corpuscles were contained in a hundred milliliters than would be present if the red cells were normal in size. Thus, the mean corpuscular copper increased from the normal of $100 \mu \mu \mu \mathrm{g}$. to $126 \mu \mu \mu g$., while the concentration of copper in the cell remained normal. On the other hand, in the infants with microcytic hypochromic anemia, although the cell size was decreased, the amount of copper per cell remained at the normal level with the result that the concentration of copper within the cell was increased. In the adults with iron deficiency anemia, the amount of copper per cell was reduced in proportion to the reduction in cell size so that the corpuscular copper concen- 
tration was normal in the microcytes. In five patients with hyperthyroidism, low values for cell copper were found.

Our observations on the copper content of the erythrocytes in various clinical conditions are in some instances at variance with the observations of Heilmeyer, Keiderling, and Stüwe (5) and with preliminary studies from this laboratory (38). The most likely explanation for this discrepancy would seem to be that $\mathrm{RBC}$ copper values have been calculated heretofore, whereas they were actually determined on washed erythrocytes in the present study.

In view of the remarkable morphological and chemical similarities between the anemia of copper deficiency and that of iron deficiency in swine (39, 40) and in the light of the reports that occasionally an infant with iron deficiency anemia responds only to therapy with iron plus copper (34), it is worth emphasizing that none of the infants with microcytic hypochromic anemia in this study exhibited hypocupremia, despite the fact that several had subsisted entirely on a milk diet for months.

The results of the studies on plasma iron are consistent with those previously reported from this laboratory (16), except that the values in acute leukemia were high and a few normal values were found in patients with infection where hypoferremia is characteristic. We have not found reports of determinations of iron and the iron-binding capacity of the plasma in infants with iron deficiency anemia. Our results suggest that the alterations are the same as in adults. The significance of changes in plasma iron in various clinical conditions has been discussed elsewhere (16).

From these studies it is evident that the copper within the red cells fluctuates very little in disease and represents a much more stable fraction than does plasma copper. This suggests that the copper is an essential constituent of the red cell although its functional significance is not at all understood. On the other hand, an increase in plasma copper occurs in a variety of circumstances and is, therefore, a rather non-specific change. Hypercupremia occurs in acute infections and in many other conditions unaccompanied by any obvious alteration in erythropoiesis. In subsequent papers in this series studies will be presented which deal with the correlation of the serum copper level with various protein fractions (25), the transportation mechanism for copper in plasma (41), and various factors which influence the plasma copper level in experimental animals (42).

\section{SUMMARY}

1. The results of measurements of whole blood, plasma and red cell (RBC) copper, as well as plasma iron determinations in pregnancy and in a variety of pathological states, are presented.

2a. In 30 pregnant subjects whole blood copper ranged from 130 to $277 \mu \mathrm{g}$. per $100 \mathrm{ml}$. blood while plasma copper ranged from 150 to $285 \mu \mathrm{g}$. per $100 \mathrm{ml}$. plasma. These values are significantly higher than normal. RBC copper was normal, as was the plasma iron.

$2 \mathrm{~b}$. In the majority of patients with various subacute or chronic infections, both whole blood and plasma copper values were greater than normal. RBC copper was usually normal. As compared with the normal, no difference in the rate of removal of copper from the plasma was observed in a patient with infection.

2c. Hypercupremia, due to an increase in plasma copper, was also observed in acute leukemia, Hodgkin's disease, hemochromatosis, aplastic or primary refractory anemia, hyperthyroidism and, less consistently, in chronic leukemia, lymphosarcoma, pernicious anemia, iron deficiency anemia, hypothyroidism, and collagen disorders.

2d. Normal values were observed in polycythemia vera.

2e. Hypocupremia was found only in "lipoid" nephrosis and in hepatolenticular degeneration and is probably related to the increased urinary excretion of copper in these conditions.

3. Significantly low $R B C$ copper values were observed only in cases of hyperthyroidism. Significantly high values were obtained only in infants with iron deficiency anemia. The mean corpuscular copper was within normal limits (100 $\mu \mu \mu \mathrm{g}$.) in all instances except in pernicious anemia where increased values $(125 \mu \mu \mu \mathrm{g}$.) were observed.

4. There was no correlation between the occurrence of hypercupremia and either hyperferremia or hypoferremia.

5. Changes in blood copper in children were similar to but often more striking than those occurring in adults. This was observed particu- 
larly in children with infections, acute leukemia, Hodgkin's disease and iron deficiency anemia.

6. In leukemia the administration of adrenocorticotrophic hormone (ACTH) was associated with a decrease in plasma copper values, whether or not a clinical remission was induced by such therapy.

\section{ACKNOWLEDGMENTS}

We are indebted to Miss Helen Ashenbrucker, Miss Doris Kurth, Miss Jean Robinson, Miss Betty Tatting and Mrs. Jean Van Dilla for technical assistance. The "Cupralene" was kindly supplied by Dr. J. M. Carlisle, Merck and Company, Rahway, New Jersey.

\section{REFERENCES}

1. Lahey, M. E., Gubler, C. J., Cartwright, G. E., and Wintrobe, M. M., Studies on copper metabolism. VI. Blood copper in normal human subjects. J. Clin. Invest., 1953, 32, 322.

2. Gubler, C. J., Lahey, M. E., Ashenbrucker, H., Cartwright, G. E., and Wintrobe, M. M., Studies on copper metabolism. I. A method for the determination of copper in whole blood, red blood cells and plasma. J. Biol. Chem., 1952, 196, 209.

3. Krebs, H. A., Uber das Kupfer im menschlichen Blutserum. Klin. Wchnschr., 1928, 7, 584.

4. Fay, J., Cartwright, G. E., and Wintrobe, M. M., Studies on free erythrocyte protoporphyrin, serum iron, serum iron-binding capacity and plasma copper during normal pregnancy. J. Clin. Invest., 1949, 28, 487.

5. Heilmeyer, L., Keiderling, W., and Stüwe, G., Kupfer und Eisen als körpereigene Wirkstoffe und ihre Bedeutung beim Krankheitsgeschehen. Fischer, Jena, 1941.

6. Holmberg, C. G., Uber die Verteilung des Kupfers zwischen Plasma und roten Blutkörperchen bei extremen physiologishen Virschiebungen im $\mathrm{Cu}$-Gehalt des Blutes. Acta physiol. Scandinav., 1941, $2,71$.

7. Locke, A., Main, E. R., and Rosbash, D. O., The copper and nonhemoglobinous iron contents of the blood serum in disease. J. Clin. Invest., 1932, 11, 527.

8. Nielsen, A. L., On serum copper. IV. Pregnancy and parturition. Acta med. Scandinav., 1944, 118, 92.

9. Sachs, A., Levine, V. E., and Fabian, A. A., Copper and iron in human blood. I. Normal men and women. Arch. Int. Med., 1935, 55, 227.

10. Sachs, A., Levine, V. E., Griffith, W. O., and Hansen, C. H., Copper and iron in human blood; comparison of maternal and fetal blood after normal delivery and after Ceasarean section. Am. J. Dis. Child., 1938, 56, 787.

11. Sachs, A., Levine, V. E., Hill, F. C., and Hughes, R., Copper and iron in human blood. Arch. Int. Med., 1943, 71, 489.
12. Sarata, U., Studies in the biochemistry of copper. VI. Copper in relation to the menstruation and pregnancy with the copper content of men's blood. Japan. J. M. Sc., II. Biochem., 1935, 3, 1.

13. Thompson, R. H. S., and Watson, D., Serum copper levels in pregnancy and pre-eclampsia. J. Clin. Path., 1949, 2, 193.

14. Tompsett, S. L., and Anderson, D. F., The copper content of the blood in pregnancy. Brit. J. Exper. Path., 1935, 16, 67.

15. Cartwright, G. E., Lauritsen, M. A., Jones, P. J., Merrill, I. M., and Wintrobe, M. M., The anemia of infection. I. Hypoferremia, hypercupremia, and alterations in porphyrin metabolism in patients. J. Clin. Invest., 1946, 25, 65.

16. Cartwright, G. E., Huguley, C. M., Ashenbrucker, H., Fay, J., and Wintrobe, M. M., Studies on free erythrocyte protoporphyrin, plasma iron and plasma copper in normal and anemic subjects. Blood, 1948, 3, 501 .

17. Gorter, E., Copper and anemia. Am. J. Dis. Child., 1933, 46, 1066.

18. Munch-Petersen, S., On serum copper in angina simplex and in infectious mononucleosis. Acta med. Scandinav., 1948, 131, 588.

19. Robinson, J. C., A simple method for determining serum copper. J. Biol. Chem., 1949, 179, 1103.

20. Sachs, A., The effect of bleeding ulcers and hemorrhagic anemia upon whole blood copper and iron. Am. J. Digest. Dis. \& Nutrition, 1936, 4, 803.

21. Cumings, J. N., The effects of B.A.L. in hepatolenticular degeneration. Brain, 1951, 74, 10.

22. Sachs, A., Levine, V. E., and Griffith, W. O., Blood copper and iron in Addison's disease. Proc. Soc. Exper. Biol. \& Med., 1937, 37, 486.

23. Nielsen, A. L., Serum copper. V. Thyrotoxicosis and myxoedema. Acta med. Scandinav., 1944, 118, 431.

24. Kelley, V. C., Acute phase reactants. I. Serum monoglucosamine polysaccharides in patients with rheumatic fever and related conditions. J. Ped., 1952, 40, 405.

25. Lahey, M. E., Gubler, C. J., Brown, D. M., Smith, E. L., Jager, B. V., Cartwright, G. E., and Wintrobe, M. M., Studies on copper metabolism. VIII. The correlation between the serum copper level and various serum protein fractions. J. Lab. \& Clin. Med., to be published.

26. Munch-Petersen, S., On the amount of copper in human erythrocytes at different serum copper levels. Scandinav. J. Clin. \& Lab. Invest., 1950, $2,53$.

27. Pedrero, E., Jr., and Kozelka, F. L., Effect of various pathological conditions on the copper content of human tissues. Arch. Path., 1951, 52, 447.

28. Pedrero, E., Jr., and Kozelka, F. L., Effect of copper on hepatic tumors produced by $3^{\prime}$-methyl-4 dimethylaminoazobenzene. Arch. Path., 1951, 52, 455.

29. Bearn, A. G., and Kunkel, H. G., Biochemical abnormalities in Wilson's disease. J. Clin. Invest., 1952, 31, 616. 
30. Sachs, A., Levine, V. E., and Griffith, W. O., Blood iron and copper in hemochromatosis. Proc. Soc. Exper. Biol. \& Med., 1936, 35, 332.

31. Wintrobe, M. M., Clinical Hematology, 3d ed. Philadelphia, Lea \& Febiger, 1951.

32. Hamilton, L. D., Gubler, C. J., Cartwright, G. E., and Wintrobe, M. M., Diurnal variation in the plasma iron level of man. Proc. Soc. Exper. Biol. \& Med., 1950, 75, 65 .

33. Cartwright, G. E., and Wintrobe, M. M., Chemical, clinical and immunological studies on the products of human plasma fractionation. XXXIX. The anemia of infection. Studies on the iron-binding capacity of serum. J. Clin. Invest., 1949, 28, 86.

34. Axtrup, S., The blood copper in anaemias of children with special reference to premature cases. A.B.P.H. Linstedts Univ.-Bokhandel; Hakan Ohlssons Boktrycheri, Lund., 1946.

35. Althausen, T. L., Doig, R. K., Weiden, S., Motteram, R., Turner, C. N., and Moore, A., Hemochromatosis. Arch. Int. Med., 1951, 88, 553.

36. Munch-Petersen, S., On the copper content in urine in proteinuria. Scandinav. J. Clin. \& Lab. Invest., 1950, 2, 337.
37. Denny-Brown, D., and Porter, H., The effect of BAL (2,3-dimercaptopropanol) on hepatolenticular degeneration (Wilson's disease). New England J. Med., 1951, 245, 917.

38. Cartwright, G. E., Copper metabolism in human subjects, in Copper Metabolism: A Symposium on Animal, Plant and Soil Relationships, edited by W. D. McElroy and B. Glass. Johns Hopkins University Press, Baltimore, 1950, pp. 274-312.

39. Lahey, M. E., Gubler, C. J., Chase, M. S., Cartwright, G. E., and Wintrobe, M. M., Studies on copper metabolism. II. Hematologic manifestations of copper deficiency in swine. Blood, 1952, 7, 1053.

40. Gubler, C. J., Lahey, M. E., Chase, M. S., Cartwright, G. E., and Wintrobe, M. M., Studies on copper metabolism. III. The metabolism of iron in copper deficient swine. Blood, 1952, 7, 1075.

41. Gubler, C. J., Lahey, M. E., Cartwright, G. E., and Wintrobe, M. M., Studies on copper metabolism. IX. The transportation of copper in blood. J. Clin. Invest., to be published.

42. Gubler, C. J., Lahey, M. E., Cartwright, G. E., and Wintrobe, M. M., Studies on copper metabolism. $X$. Factors influencing the plasma copper level of the albino rat. Am. J. Physiol., to be published. 